\title{
Multiple-Criteria Decision-Making (MCDM) Techniques for Business Processes Information Management
}

\author{
Edmundas Kazimieras Zavadskas ${ }^{1,2} \mathbb{D}$, Jurgita Antucheviciene ${ }^{1, * \mathbb{D}}$ and Prasenjit Chatterjee 3 \\ 1 Department of Construction Management and Real Estate, Vilnius Gediminas Technical University, \\ Sauletekio al. 11, Vilnius LT-10223, Lithuania; edmundas.zavadskas@vgtu.lt \\ 2 Institute of Sustainable Construction, Vilnius Gediminas Technical University, Sauletekio al. 11, \\ Vilnius LT-10223, Lithuania \\ 3 Department of Mechanical Engineering, MCKV Institute of Engineering, Howrah-711204, India; \\ prasenjit2007@gmail.com \\ * Correspondence: jurgita.antucheviciene@vgtu.lt; Tel.: +370-5-274-5233
}

Received: 21 December 2018; Accepted: 21 December 2018; Published: 23 December 2018

\begin{abstract}
Information management is a common paradigm in modern decision-making. A wide range of decision-making techniques have been proposed in the literature to model complex business processes. In this Special Issue, 16 selected and peer-reviewed original research articles contribute to business information management in various current real-world problems by proposing crisp or uncertain multiple-criteria decision-making (MCDM) models and techniques, mostly including multi-attribute decision-making (MADM) approaches in addition to a single paper proposing an interactive multi-objective decision-making (MODM) approach. The papers are mainly concentrated in three application areas: supplier selection and rational order allocation, the evaluation and selection of goods or facilities, and personnel selection/partner selection. A number of new approaches are proposed that are expected to attract great interest from the research community.
\end{abstract}

Keywords: multiple-criteria decision-making (MCDM); multi-attribute decision-making (MADM); fuzzy sets; neutrosophic sets; rough sets; aggregation operators; adaptive neuro-fuzzy inference system (ANFIS)

\section{Introduction}

Complex information management is an important part of activity in modern decision-making. Today's real-world problems involve multiple data sets, some precise or objective and some uncertain or subjective.

A wide range of statistical and non-statistical decision-making techniques have been proposed in the literature to model complex business or engineering processes. Multiple-criteria decision-making $(\mathrm{MCDM})$ methods are among the techniques that have recently been gaining extraordinary popularity and wide applications [1].

Due to lack of precise data in real-word problems, statistical methods (i.e., probability theory) are useful in modeling processes with incomplete or inaccurate data. Meanwhile, non-statistical methods (i.e., fuzzy set theory, rough set theory, possibility theory, or fuzzy neural networks) are useful for modeling complex systems with imprecise, ambiguous, or vague data. Fuzzy MCDM techniques and their applications are constantly developing [2,3], starting from type-1 fuzzy sets and further extending to complex fuzzy sets [4]. A neuro-fuzzy approach recently has emerged as a popular technique for addressing problem-solving in the business environment [5]. A new emerging tool for uncertain 
data processing, known as neutrosophic set, has also been successfully applied for decision-making problems [6]. In addition, rough set theory is a powerful method for dealing within formation systems that demonstrate inconsistency, and fuzzy-rough models are able to analyze inconsistent and vague data [7]. On the basis of fuzzy set theory and aggregation operator theory, numerous decision-making theories have been developed and information aggregation methods under fuzzy aggregation operator have been suggested [8].

Discussions of the relationship and combination of fuzzy and probabilistic representations of uncertainties in multiple-attribute engineering and management problems have lasted for many years and do not seem to be finished to date [9]. Therefore, hybrid MCDM models are quickly emerging as alternative methods for information modeling [10-12].

One can notice that crisp, fuzzy, or hybrid decision-making techniques are extremely widely applied for transportation, logistics, and supplier selection problems, requiring the effective management of information when evaluating alternative solutions and making optimal decisions [13-18]. The next rather frequent application of MCDM techniques is for the assessment of service quality in different industries and various types of economic activities [19,20].

Therefore, based on the above-discussed items that highlight the topicality of the issue, we invited authors to submit their original research articles and disseminate their new ideas related to MCDM models and techniques to rationalize the complex process of business information management and optimal decision-making. Reviewers and editors approved 16 papers from all the received submissions. Next, we discuss the contribution of the published papers to the aim of the Special Issue in terms of proposed decision-making approaches and application areas.

\section{Contributions}

This Special Issue includes 16 original research articles. The papers contribute to decision-making techniques for business processes information management by offering optimal choice benefits through a variety of methodologies and tools, mainly including novel or extended decision-making models and methods in uncertain environments.

The topics of the Special Issue gained attention in Europe and Asia. A total of 48 authors from seven countries contributed to the Issue (Figure 1).

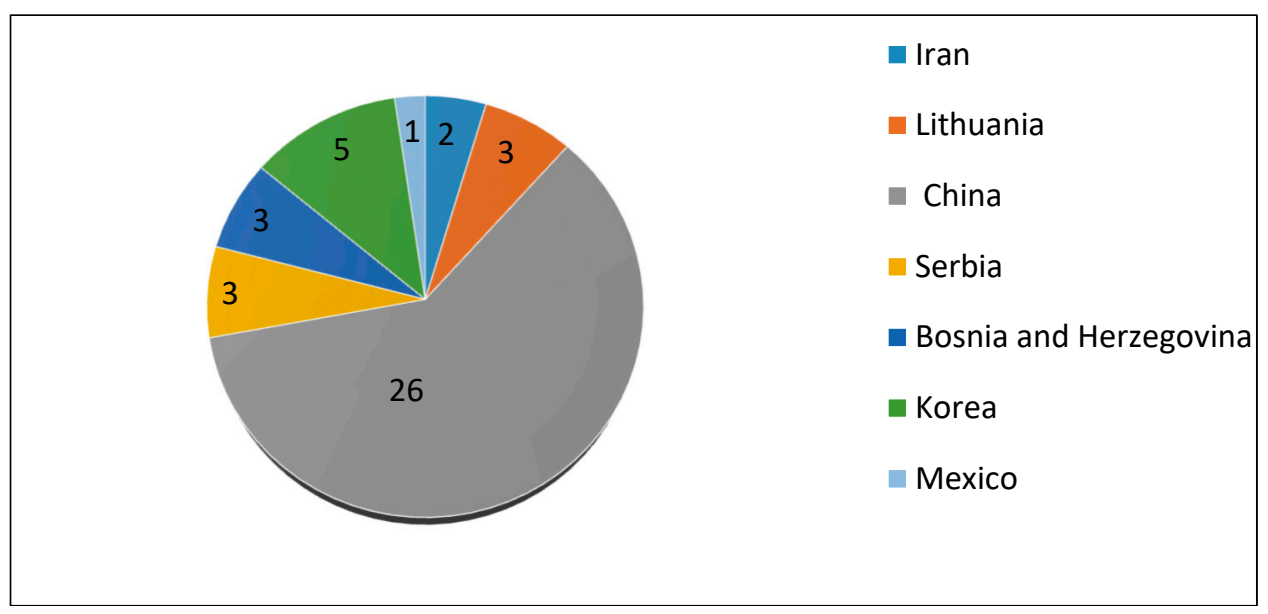

Figure 1. Distribution of authors by country.

The distribution of papers according to authors' affiliation is presented in Table 1. Authors from China contributed to 10 papers; authors and co-authors from Bosnia and Herzegovina, Serbia, and Lithuania contributed three papers. Authors from Korea prepared two papers, an author from Mexico contributed one paper, and researchers from Iran co-authored a single paper with Lithuanian researchers. 
Table 1. Publications by country.

\begin{tabular}{cc}
\hline Countries & Number of Papers \\
\hline China & 10 \\
Korea & 2 \\
Bosnia and Herzegovina-Serbia & 1 \\
Bosnia and Herzegovina-Serbia-Lithuania & 1 \\
Iran-Lithuania & 1 \\
Mexico & 1 \\
\hline
\end{tabular}

The papers are classified according to decision-making approaches into several groups, as presented in Figure 2. Mostly the papers propose uncertain multi-attribute decision-making (MADM) models and techniques, while a single paper proposes a multi-objective decision-making (MODM) approach. A significant part of papers are related to information aggregation operators (nine papers), including Pythagorean fuzzy and Dombioperators, probabilistic fuzzy and hesitant information aggregation (seven papers). Two papers analyze operations and aggregation methods of neutrosophic numbers, covering neutrosophic Bonferroni mean operators and linguistic neutrosophic aggregation. Two research works propose rough and fuzzy-rough MADM approaches and one paper presents a fuzzy MADM dynamic approach for the optimal choice of alternatives. Another research paper develops an adaptive neuro-fuzzy inference system (ANFIS) for the optimization of problem solutions, one paper proposes an interactive multi-objective optimization model, one paper uses an interval multiplicative preference relations (IMPRs) approach, and one paper develops a deterministic finite automata-based model.

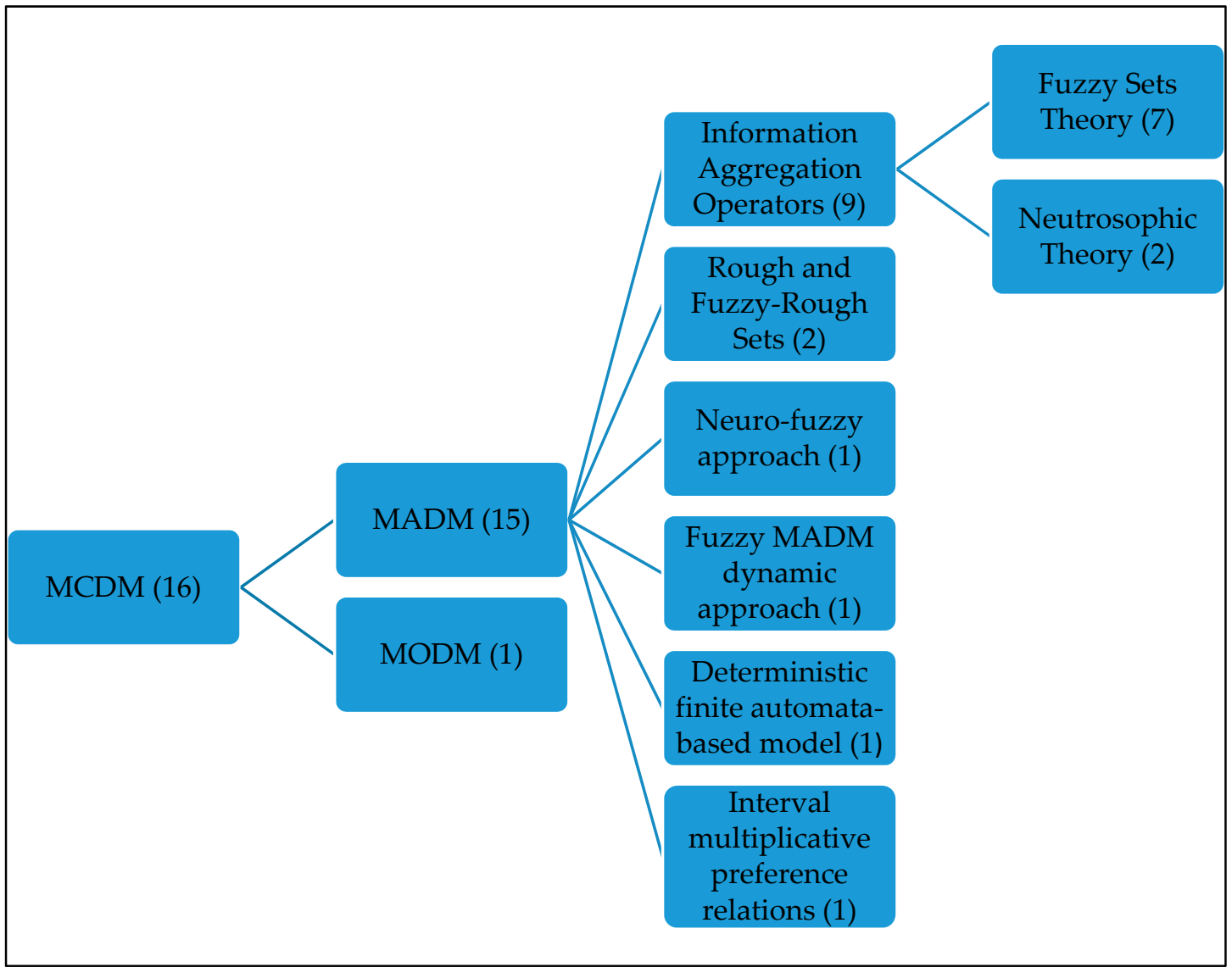

Figure 2. Decision-making approaches. 
The case studies and application examples of the proposed approaches presented in the papers are mainly concentrated in three areas (Figure 3). One group of papers suggests different approaches for supplier assessment and selection, including the topical question of green supplier selection, as well as order allocation and the optimization of queuing systems in warehouses. The next group of applications is related to the evaluation of facilities or goods from the viewpoint of consumers such as brand selection, airline evaluation, or choosing a hospital, and from the view point of enterprise managers such as enterprise resource planning (ERP) system selection, technology selection, or the evaluation of investment alternatives. The last group of papers suggests multiple-criteria approaches for personnel or partner selection optimization as well as job options evaluation.

Logistics, supplier
selection, and rational
order allocation
- Optimization of a
queuing system in
warehouses
- Green supplier
assessment
- Order allocation with
supplier selection
- Supplier selection with
the impact on the
efficiency of the supply
chain

$\begin{gathered}\text { Evaluation and selection } \\ \text { of goods, facilities, or } \\ \text { activities }\end{gathered}$
- Evaluation of new market
- Enterprise resource
planning (ERP) system
selection
- Choosing a hospital
- Choosing a brand to buy
an air conditioner
- Selection of
propulsion/manoeuvring
system of a ferry
- Selection of investment
alternatives

Personnel
selection/partner selection
- Choosing a software
engineer for a company
(two papers)
- Graduate's job options
evaluation
- Evaluation a
subcontractor for
outsourcing
- Partner selection for an
enterprise

Figure 3. Research areas of case studies.

The Special Issue received a paper related to subcontractor evaluation in a dynamic multi-attribute group decision-making (MAGDM) environment using a new fuzzy approach based on the EDAS (Evaluation based on Distance from Average Solution) method [21]. Another paper proposes an extended bi-directional projection method for solving MADM problems with Pythagorean uncertain linguistic variables [22]. A paper focusing on supplier selection in a polyvinyl chloride (PVC) carpentry company develops a new model using rough analytical hierarchical process (AHP) for criteria weight calculation, followed by the application of the rough weighted aggregated sum product assessment (WASPAS) method to determine the ranking preorders of the alternative suppliers [23]. One more paper related to supply chain management (SCM) offers an interactive multi-objective optimization approach for the supplier selection and order allocation problem. In this paper, the concept of desirability is also incorporated into the optimization model to take into account the principles of diminishing marginal utility [24]. For uncertainty and incompleteness in assessing green suppliers, an approach based on rough ANP and evidence theory is proposed [25]. A compound expression tool of interval-valued dual hesitant fuzzy unbalanced linguistic set (IVDHFUBLS) is proposed to help decision-makers by elucidating their assessments more comprehensively and completely. It also prioritizes weighted aggregation operator for IVDHFUBLS-based decision-making scenarios and then analyzes its properties and special cases [26]. A novel convex combination of multi-hesitant fuzzy numbers (MHFNs) is introduced along with some aggregation operators and their corresponding properties are discussed in detail [27]. Two papers focus on the analytical investigation of properties and some special cases related to the parameter vector for a Muirhead mean (MM) operator in a Pythagorean fuzzy context [28,29]. A MADM model is developed in a linguistic cubic variable (LCV) setting on the basis of Dombi-weighted geometric average (DWGA) [30]. One paper presents the 
concept of a single-valued linguistic neutrosophic interval linguistic number and some weighted arithmetic averaging and weighted geometric averaging operators are proposed and their properties are investigated [31]. Score function and accuracy function are proposed, satisfying the ranking principle and extending the operators under a neutrosophic environment [32]. Hesitant probabilistic fuzzy MAGDM is studied [33]. An adaptive neuro-fuzzy inference system (ANFIS) model is developed for a warehouse system with two servers to define queuing system optimization parameters [34]. A quick algorithm for a binary discernibility matrix simplification using deterministic finite automata is proposed along with definitions of row and column relations [35]. A methodology is proposed to provide reliable consistent and in consensus Interval Multiplicative Preference Relations (IMPRs) using Hadamard's operator [36].

\section{Conclusions}

The topics of this Special Issue piqued the interest of researchers both in Asia and in Europe; researchers from seven countries authored and co-authored papers published in the Issue.

Although the announced topics of the Special Issue covered MADM and MODM theories, mainly MADM approaches have been suggested, while a single research paper proposed a MODM model. Therefore, multi-attribute decision-making techniques proved to be highly applicable for business processes information management.

Most approaches suggested decision models under uncertainty, proposing extensions of decision-making methods in combination with fuzzy, rough, and neutrosophic sets theory. Particular attention was devoted to information aggregation operators; 65 percent of papers dealt with the item.

The application areas of proposed MCDM techniques mainly covered logistics and supply chains optimization, the selection of goods or facilities, and personnel selection.

Author Contributions: All authors contributed equally to this work.

Acknowledgments: The authors express their gratitude to the journal Information for offering an academic platform for researchers to contribute and exchange their recent findings in a sustainable environment.

Conflicts of Interest: The authors declare no conflict of interest.

\section{References}

1. Mardani, A.; Jusoh, A.; Nor, K.M.D.; Khalifah, Z.; Zakwan, N.; Valipour, A. Multiple criteria decision-making techniques and their applications- A review of the literature from 2000 to 2014. Econ. Res.-Ekon. Istraz. 2015, 28, 516-571. [CrossRef]

2. Mardani, A.; Jusoh, A.; Zavadskas, E.K. Fuzzy multiple criteria decision-making techniques and applications-Two decades review from 1994 to 2014. Expert Syst. Appl. 2015, 42, 4126-4148. [CrossRef]

3. Kahraman, C.; Onar, S.C.; Oztaysi, B. Fuzzy Multicriteria Decision-Making: A Literature Review. Int. J. Comput. Intell. Syst. 2015, 8, 637-666. [CrossRef]

4. Yazdanbakhsh, O.; Dick, S. A systematic review of complex fuzzy sets and logic. Fuzzy Sets Syst. 2018, 338, 1-22. [CrossRef]

5. Rajab, S.; Sharma, V. A review on the applications of neuro-fuzzy systems in business. Artif. Intell. Rev. 2018, 49, 481-510. [CrossRef]

6. Khan, M.; Son, L.H.; Ali, M.; Chau, H.T.M.; Na, N.T.N.; Smarandache, F. Systematic review of decision making algorithms in extended neutrosophic sets. Symmetry 2018, 10, 314. [CrossRef]

7. Mardani, A.; Nilashi, M.; Antucheviciene, J.; Tavana, M.; Bausys, R.; Ibrahim, O. Recent fuzzy generalisations of rough sets theory: A systematic review and methodological critique of the literature. Complexity 2017, 2017, 1608147. [CrossRef]

8. Mardani, A.; Nilashi, M.; Zavadskas, E.K.; Awang, S.R.; Zare, H.; Jamal, N.M. Decision making methods based on fuzzy aggregation operators: Three decades review from 1986 to 2017. Int. J. Inf. Technol. Decis. Mak. 2018, 17, 391-466. [CrossRef] 
9. Antucheviciene, J.; Kala, Z.; Marzouk, M.; Vaidogas, E.R. Solving Civil Engineering Problems by Means of Fuzzy and Stochastic MCDM Methods: Current State and Future Research. Math. Probl. Eng. 2015, 2015, 362579. [CrossRef]

10. Zavadskas, E.K.; Antucheviciene, J.; Turskis, Z.; Adeli, H. Hybrid multiple-criteria decision-making methods: A review of applications in engineering. Sci. Iran. 2016, 23, 1-20.

11. Zavadskas, E.K.; Govindan, K.; Antucheviciene, J.; Turskis, Z. Hybrid multiple criteria decision-making methods: A review of applications for sustainability issues. Econ. Res.-Ekon. Istraz. 2016, 29, 857-887. [CrossRef]

12. Shen, K.Y.; Zavadskas, E.K.; Tzeng, G.H. Updated discussions on “Hybrid multiple criteria decision-making methods: A review of applications for sustainability issues". Econ. Res.-Ekon. Istraz. 2018, 31, 1437-1452. [CrossRef]

13. Mardani, A.; Zavadskas, E.K.; Khalifah, Z.; Jusoh, A.; Nor, K. Multiple criteria decision-making techniques in transportation systems: A systematic review of the state of the art literature. Transport 2016, 31, 359-385. [CrossRef]

14. Keshavarz Ghorabaee, M.; Amiri, M.; Zavadskas, E.K.; Antucheviciene, J. Supplier evaluation and selection in fuzzy environments: A review of MADM approaches. Econ. Res.-Ekon. Istraz. 2017, 30, 1073-1118. [CrossRef]

15. Govindan, K.; Hasanagic, M. A systematic review on drivers, barriers, and practices towards circular economy: a supply chain perspective. Int. J. Prod. Res. 2018, 56, 278-311. [CrossRef]

16. Govindan, K.; Soleimani, H. A review of reverse logistics and closed-loop supply chains: A Journal of Cleaner Production focus. J. Clean. Prod. 2017, 142, 371-384. [CrossRef]

17. Correia, E.; Carvalho, H.; Azevedo, S.G.; Govindan, K. Maturity models in supply chain sustainability: A systematic literature review. Sustainability 2017, 9, 64. [CrossRef]

18. Govindan, K.; Rajendran, S.; Sarkis, J.; Murugesan, P. Multi criteria decision making approaches for green supplier evaluation and selection: A literature review. J. Clean. Prod. 2015, 98, 66-83. [CrossRef]

19. Mardani, A.; Jusoh, A.; Zavadskas, E.K.; Kazemilari, M.; Ahmad, U.N.U.; Khalifah, Z. Application of multiple criteria decision making techniques in tourism and hospitality industry: A systematic review. Transform. Bus. Econ. 2016, 15, 192-213.

20. Mardani, A.; Jusoh, A.; Zavadskas, E.K.; Khalifah, Z.; Nor, K.M. Application of multiple-criteria decision-making techniques and approaches to evaluating of service quality: A systematic review of the literature. J. Bus. Econ. Manag. 2015, 16, 1034-1068. [CrossRef]

21. Keshavarz-Ghorabaee, M.; Amiri, M.; Zavadskas, E.K.; Turskis, Z.; Antucheviciene, J. A dynamic fuzzy approach based on the EDAS method for multi-criteria subcontractor evaluation. Information 2018, 9, 68. [CrossRef]

22. Wang, H.; He, S.; Pan, X. A new bi-directional projection model based on pythagorean uncertain linguistic variable. Information 2018, 9, 104. [CrossRef]

23. Stojić, G.; Stević, Ž.; Antuchevičienè, J.; Pamučar, D.; Vasiljević, M. A novel rough WASPAS approach for supplier selection in a company manufacturing PVC carpentry products. Information 2018, 9, 121. [CrossRef]

24. Lee, P.; Kang, S. An interactive multiobjective optimization approach to supplier selection and order allocation problems using the concept of desirability. Information 2018, 9, 130. [CrossRef]

25. Li, L.; Wang, H. A green supplier assessment method for manufacturing enterprises based on rough ANP and evidence theory. Information 2018, 9, 162. [CrossRef]

26. Qi, X.-W.; Zhang, J.-L.; Liang, C.-Y. Multiple attributes group decision making under interval-valued dual hesitant fuzzy unbalanced linguistic environment with prioritized attributes and unknown decision makers' weights. Information 2018, 9, 145. [CrossRef]

27. Mei, Y.; Peng, J.; Yang, J. Convex aggregation operators and their applications to multi-hesitant fuzzy multi-criteria decision making. Information 2018, 9, 207. [CrossRef]

28. Xu, Y.; Shang, X.; Wang, J. Pythagorean fuzzy interaction Muirhead means with their application to multi-attribute group decision making. Information 2018, 9, 157. [CrossRef]

29. Zhu, J.; Li, Y. Pythagorean fuzzy Muirhead mean operators and their application in multiple-criteria group decision-making. Information 2018, 9, 142. [CrossRef]

30. Lu, X.; Ye, J. Dombi Aggregation operators of linguistic cubic variables for multiple attribute decision making. Information 2018, 9, 188. [CrossRef] 
31. Ye, J.; Cui, W. Operations and aggregation methods of single-valued linguistic neutrosophic interval linguistic numbers and their decision making method. Information 2018, 9, 196. [CrossRef]

32. Mo, J.; Huang, H.-L. Dual generalized nonnegative normal Neutrosophic Bonferroni mean operators and their application in multiple attribute decision making. Information 2018, 9, 201. [CrossRef]

33. Park, J.H.; Park, Y.K.; Son, M.J. Hesitant Probabilistic Fuzzy Information Aggregation Using Einstein Operations. Information 2018, 9, 226. [CrossRef]

34. Stojčić, M.; Pamučar, D.; Mahmutagić, E.; Stević, Ž. Development of an ANFIS model for the optimization of a queuing system in the warehouse. Information 2018, 9, 240. [CrossRef]

35. Zhang, N.; Li, B.; Zhang, Z.; Guo, Y. A quick algorithm for binary discernibility matrix simplification using deterministic finite automata. Information 2018, 9, 314. [CrossRef]

36. López-Morales, V. Multiplecriteria decision-making in heterogeneous groups of management experts. Information 2018, 9, 300. [CrossRef]

(C) 2018 by the authors. Licensee MDPI, Basel, Switzerland. This article is an open access article distributed under the terms and conditions of the Creative Commons Attribution (CC BY) license (http://creativecommons.org/licenses/by/4.0/). 